\title{
Aplikasi Amelioran Di Tanah Sulfat Masam terhadap Dinamika Amonium dan Nitrat Pada Beberapa Stadia Umur Padi
}

\author{
Application of Ameliorant in Acid Sulfate Soil to Dynamic of Ammonium and Nitrate \\ at Several Rice Stage Age
}

\author{
Nurlaila $^{1}$, Ahmad Fathul Aziz ${ }^{1 *}$, Tuti Heiriyani ${ }^{1}$, Nukhak Nufita Sari ${ }^{1}$ \\ ${ }^{1}$ Jurusan Agroekoteknologi Universitas Lambung Mangkurat Banjarbaru
}

*Email: afathulaziz@gmail.com

\begin{abstract}
Pemberian amelioran berupa bokashi dari limbah baglog jamur tiram yang memiliki kandungan nitrogen dan pH tinggi perlu dilakukan untuk memperbaiki sifat fisik, kimia, dan biologi tanah sulfat masam. Peningkatan $\mathrm{pH}$ akan mempengaruhi penyerapan nutrisi seperti amonium dan nitrat. Penelitian ini bertujuan untuk mengetahui pengaruh pemberian bokashi terhadap dinamika amonium, nitrat, dan serapan $\mathrm{N}$ padi di tanah sulfat masam pada tiga stadia pertumbuhan padi yang berbeda (stadia vegetatif penuh, awal muncul malai, dan pengisian malai).

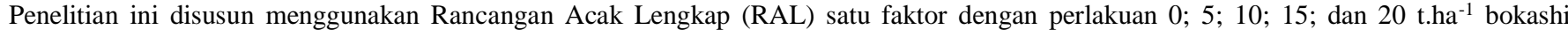
limbah baglog jamur tiram yang diulang sebanyak lima kali. Pola yang sama pada semua perlakuan menunjukkan ketersediaan amonium dan nitrat menurun sedangkan serapan $\mathrm{N}$ meningkat. Warna daun merupakan indikator serapan $\mathrm{N}$ dengan skala warna daun tertinggi terdapat pada tahap awal muncul malai, yang menunjukkan bahwa $\mathrm{N}$ diserap oleh tanaman yang digunakan untuk pembentukan malai. Skala warna daun ini mengalami penurunan sepanjang stadia pengisian malai terlihat dari peningkatan serapan $\mathrm{N}$ pada akhir stadia pengisian malai. Pemberian amelioran mempengaruhi dinamika amonium dan nitrat tanah, yang berimplikasi pada serapan dan warna daun padi di tanah sulfat masam.
\end{abstract}

Keywords: $\mathrm{NH}_{4}^{+} ; \mathrm{NO}_{3} ;$; Bokashi; Baglog; Padi

\section{Pendahuluan}

Luasan lahan sawah di Indonesia setiap tahunnya mengalami penyempitan. Menyempitnya lahan dikarenakan beralih fungsinya lahan sawah menjadi perumahan atau industri. Tahun 2016 lahan sawah di Indonesia seluas 8,18 juta ha yang berupa sawah irigasi dan sawah non irigasi, sedangkan pada tahun 2017 luasan sawah menjadi 8,16 juta ha atau menyusut $0,24 \%$ dan tahun 2018 lahan sawah tersebut semakin menyusut menjadi 7,1 juta ha atau berkurang sebanyak 12,99\% (Kementan, 2019).

Menyempitnya lahan sawah mengharuskan petani mencari alternatif lain lokasi lahan untuk budidaya padi. Lahan yang cukup berpotensi untuk dijadikan lahan sawah yaitu pemanfaatan tanah sulfat masam. Tanah sulfat masam banyak ditemukan pada lahan rawa. Lahan rawa di Kalimantan Selatan sendiri sangat luas dan masih belum banyak dimanfaatkan. Luas lahan potensial di Kalimantan Selatan sebanyak 4.969.824 ha dan 110.894 ha merupakan lahan rawa pasang surut (BPS Provinsi Kalimantan Selatan, 2014). Tanah sulfat masam mengandung pirit yang apabila teroksidasi akan meningkatkan kemasaman tanah yang dapat menurunkan kesuburan tanah (Annisa dan Purwanto, 2010).

Menurunnya kesuburan tanah sulfat masam akan berpengaruh pada unsur hara yang tersedia di tanah dan akan mempengaruhi pertumbuhan vegetasi di atasnya. Salah satu unsur hara utama tanaman adalah nitrogen yang diserap dalam wujud senyawa amonium $\left(\mathrm{NH}_{4}{ }^{+}\right)$atau senyawa nitrat $\left(\mathrm{NO}_{3}{ }^{-}\right)$. Nitrogen diperlukan oleh tanaman dari awal tanam hingga panen, sehingga ketersediaan amonium dan nitrat sangat diperlukan oleh tanaman untuk pertumbuhan, akan tetapi ketersediaan amonium dan nitrat di tanah sulfat masam sangat rendah, dimana pada penelitian yang dilakukan oleh Saputra dan Sari (2021), karakteristik tanah pasang surut yang digunakan memiliki kadar amonium 21,1 ppm dan kadar nitrat $56,5 \mathrm{ppm}$. Rendahnya ketersediaan amonium dan nitrat pada tanah sulfat masam akan menyebabkan pertumbuhan tanaman terhambat, sehingga perlunya dilakukan perbaikan kualitas tanah.

Upaya perbaikan kualitas tanah sulfat masam salah satunya menggunakan amelioran. Amelioran yang dapat digunakan salah satunya bokashi limbah baglog jamur tiram. Banyak penelitian ameliorasi lahan sulfat masam dengan menggunakan bokashi, akan tetapi masih sedikit informasi terkait penelitian ameliorasi dengan menggunakan bokashi limbah baglog jamur tiram pada tanah sulfat masam. Limbah baglog jamur tiram cukup banyak ketersediannya dan belum banyak dimanfaatkan. Kandungan unsur hara pada limbah baglog jamur tiram cukup tinggi sehingga sangat potensial untuk dijadikan bokashi. Kandungan unsur hara pada limbah baglog jamur tiram diantaranya $0,23 \% \mathrm{~N}$, $0,30 \% \quad \mathrm{P}_{2} \mathrm{O}_{5}, \quad 0,2 \% \quad \mathrm{~K}_{2} \mathrm{O}, 17,93 \% \quad \mathrm{C}$-organik, $\mathrm{C} / \mathrm{N}$ rasio sebanyak 78, dan pH sebesar 8,5 (Hasbiah et al., 2017).

Tingginya $\mathrm{pH}$ yang dimiliki bokashi limbah baglog jamur tiram mengindikasikan bahwa $\mathrm{pH}$ bokashi bersifat basa, sehingga berpotensi untuk digunakan dalam meningkatkan $\mathrm{pH}$ tanah sulfat masam. Hal tersebut menjadi latar belakang tidak dilakukan pemberian kapur pertanian pada media tanam penelitian ini. Tujuan penelitian ini yaitu 
untuk mengetahui pengaruh dan dosis terbaik pemberian bokashi limbah baglog jamur tiram di tanah sulfat masam terhadap dinamika amonium dan nitrat pada beberapa stadia umur padi dan serapan $\mathrm{N}$ pada padi yang di panen.

\section{Metodologi}

Penelitian ini menggunakan bahan-bahan sebagai berikut: tanah sulfat masam, $\mathrm{H}_{2} \mathrm{O}_{2}$, limbah baglog jamur tiram, kotoran sapi, arang sekam, dedak, topsoil, EM4, gula merah, urea, SP-36, KCl, benih padi, dan bahan-bahan kimia di laboratorium. Alat-alat yang digunakan terdiri dari kotak kompos, bor tanah, sundak, papan ukur, ember, spuit, leaf color chart, spektrofotometer, alat-alat laboratorium. Penelitian ini dilaksanakan selama 5 (lima) bulan dari tanggal 27 Juli - 27 Desember 2020. Bertempat di Rumah Kaca Jurusan Agroekoteknologi, Fakultas Pertanian, Universitas Lambung Mangkurat. Rancangan dalam penelitian ini disusun menggunakan Rancangan Acak Lengkap (RAL) satu faktor. Faktor yang diteliti adalah dosis bokashi limbah baglog jamur tiram (B) yang terdiri dari 5 perlakuan, yaitu $b_{0}=0$ ton.ha ${ }^{-1}\left(0 \mathrm{~g} .10 \mathrm{~kg}^{-1}\right.$ tanah $), \mathrm{b}_{1}=5$ ton.ha- $\mathrm{h}^{-1}$ (21,36 g. $10 \mathrm{~kg}^{-1}$ tanah), $\mathrm{b}_{2}=10$ ton.ha' $\mathrm{h}^{-1}$ (42,74 g. $10 \mathrm{~kg}^{-1}$ tanah), $\mathrm{b}_{3}=15$ ton.ha- ${ }^{-1}\left(64,10 \mathrm{~g} .10 \mathrm{~kg}^{-1}\right.$ tanah $), \mathrm{b}_{4}=$ 20 ton.ha ${ }^{-1}\left(85,47\right.$ g. $10 \mathrm{~kg}^{-1}$ tanah) yang diulang sebanyak lima kali.

Pelaksanaan penelitian diawali dengan pengambilan limbah baglog jamur tiram yang didapatkan dari petani jamur tiram di Kota Banjarbaru Kalimantan Selatan. Limbah yang digunakan merupakan baglog jamur yang sudah tua dan yang terkontaminasi. Limbah kemudian dikomposkan dengan mencampur bahan berupa limbah baglog jamur tiram sebanyak $30 \mathrm{~kg}$ yang ditambahkan dengan $12 \mathrm{~kg}$ kotoran sapi, $6 \mathrm{~kg}$ arang sekam, 1,2 kg dedak, dan 0,6 kg top soil. Larutan dekomposer berupa EM4 $42 \mathrm{~mL}$ ditambahkan $30 \mathrm{~g}$ gula merah. Larutan kemudian disiramkan pada campuran bahan baku bokashi sambil ditambahkan air secukupnya dan diaduk hingga merata (Hunaepi et al., 2018). Bahan yang telah dicampur kemudian dikomposkan selama 3 minggu sampai bokashi matang dengan ciri bau seperti tanah, suhu stabil, dan warna kompos coklat kehitaman.

Tanah sulfat masam yang digunakan berasal dari Desa Sungai Rangas Kabupaten Banjar Kalimantan Selatan. Tanah yang diperlukan sebanyak $300 \mathrm{~kg}$ tanah sulfat masam. Sebelum tanah diambil dilakukan pengujian keberadaan pirit pada kedalaman 0-10 cm, 10-31 cm, 31-46 $\mathrm{cm}$, 46-65 cm, dan $>65 \mathrm{~cm}$. Keberadaan pirit ditemukan pada kedalaman $62 \mathrm{~cm}$, sehingga tanah yang diambil pada kedalaman antara 0-30 cm dengan menggunakan sundak. Tanah dibersihkan dari sisa-sisa tanaman, kemudian ditimbang seberat $10 \mathrm{~kg}$ dan dimasukkan ke dalam ember percobaan. Masing-masing ember percobaan ditambahkan bokashi limbah baglog jamur tiram sesuai dosis perlakuan. Masing-masing ember percobaan ditambahkan air hingga setinggi $3 \mathrm{~cm}$ dari permukaan tanah, kemudian diinkubasi selama 2 minggu. Selama masa inkubasi ketinggian air dipertahankan pada $3 \mathrm{~cm}$ dari permukaan tanah di dalam ember, agar tanah tidak kekeringan dan teroksidasi.
Memisahkan benih bernas padi Varietas Ciherang dengan merendamnya ke dalam air untuk memisahkan gabah isi dan gabah kosong, setelah didapatkan benih bernas kemudian direndam selama 24 jam untuk mempercepat perkecambahan. Benih padi kemudian diperam dengan memasukannya ke dalam karung goni basah agar terjaga kelembabannya selama 24 jam (Permatasari et al., 2018). Benih yang sudah memunculkan radik kemudian disemai pada media semai berupa tanah dan pupuk kandang sapi dengan perbandingan 1:1 dan dimasukkan ke dalam baki semai. Benih padi kemudian disemai di lapangan selama 14 hari dan dilakukan penyiraman ke media semai apabila kelembaban pada tanah telah berkurang. Bibit padi yang telah disemai di lapangan selama 14 hari, kemudian dipindahkan ke ember-ember percobaan sebanyak dua tanaman untuk setiap ember. Bibit ditanam dengan kedalaman penanaman $\pm 2 \mathrm{~cm}$ dan akar tertutup tanah semuanya agar tanaman tegak dan tidak rebah terkena air. Perawatan dilakukan dengan membuang gulma dan menambahkan air pada tanah dalam ember. Pemupukan juga perlu dilakukan saat awal tanam yaitu dengan dosis sebesar $230 \mathrm{~kg} \cdot \mathrm{ha}^{-1}$ urea, $100 \mathrm{~kg} \cdot \mathrm{ha}^{-1} \mathrm{SP}-36$, dan $50 \mathrm{~kg} \cdot \mathrm{ha}^{-1} \mathrm{KCl}$. Rekomendasi pemupukan N, P, K bersumber dari Permentan nomor 40 tahun 2007 di Kecamatan Martapura Barat (Deptan, 2007).

Pengamatan dilakukan pada stadia vegetatif penuh (8 MST), awal muncul malai (10 MST), dan pengisian malai (12 MST). Parameter yang diamati yaitu kadar $\mathrm{NH}_{4}^{+}$ menggunakan metode spektrofotometer dengan panjang gelombang $636 \mathrm{~nm}$. Penentuan kadar nitrat $\left(\mathrm{NO}_{3}{ }^{-}\right)$dilakukan dengan metode spektrofotometer pada panjang gelombang 494 nm (Balittan, 2009). Pengamatan warna daun dilakukan dengan menggunakan alat bagan warna daun (BWD) dengan skala 2-5. Daun tanaman yang diamati adalah daun teratas yang telah membuka penuh. Bagian tengah daun diletakkan di atas BWD dan dibandingkan warnanya, kemudian menentukan nilainya berdasarkan skala sesuai dengan BWD. Waktu pengukuran dilakukan pada pagi hari. Pengukuran dilakukan oleh orang yang sama dalam satu waktu (Erythrina, 2016). Penentuan serapan N dilakukan dengan mengambil daun tanaman yang telah dipanen kemudian dianalisis di laboratorium. Analisis yang digunakan yaitu dengan metode Kjeldahl dengan cara pengabuan basah $\mathrm{H}_{2} \mathrm{SO}_{4}$. Ekstrak kemudian diukur absorbansinya menggunakan spektrofotometer (Balittan, 2009).

Data yang didapat kehomogenannya dianalisis dengan ragam Bartlett, setelah homogen selanjutnya dianalisis menggunakan Analiysis of Varian (ANOVA) dan Duncan Multiple Range Test $(\alpha=5 \%)$ jika perlakuan berpengaruh nyata $(\mathrm{P} \leq 0,05)$.

\section{Hasil}

\section{Dinamika Amonium dan Nitrat}

Pemberian bokashi limbah baglog jamur tiram memberikan pengaruh tidak nyata terhadap kadar amonium pada stadia vegetatif penuh yang diamati pada umur $8 \mathrm{MST}$, stadia awal muncul malai (10 MST), dan stadia pengisian malai (12 MST). Pemberian bokashi limbah baglog jamur 
tiram memberikan pengaruh nyata terhadap kadar nitrat pada stadia vegetatif penuh pada umur 8 MST dan stadia pengisian malai (12 MST), akan tetapi tidak berpengaruh nyata pada stadia awal muncul malai. Kadar amonium dan nitrat tertinggi terdapat pada perlakuan 20 ton.ha ${ }^{-1}\left(b_{4}\right)$ pada ketiga stadia dan kadar terendah pada perlakuan kontrol atau $\mathrm{b}_{0}$ di ketiga stadia (Gambar 1 dan 2).

Kadar amonium dan nitrat saat memasuki vegetatif penuh lebih tinggi jika dibandingkan dengan kadar amonium saat awal tanam. Kadar amonium saat awal tanam pada perlakuan $b_{0}$ yaitu 1,21 ppm, $b_{1}$ sekitar 1,42 ppm, $b_{2}$ sekitar 1,24 ppm, $b_{3}$ sekitar1,67 ppm, dan $b_{4}$ sekitar 1,70 ppm. Kadar nitrat saat awal tanam cukup rendah dimana pada perlakuan $b_{0}$ kadar awalnya $1,20 \mathrm{ppm}, \mathrm{b}_{1}$ sekitar $1,32 \mathrm{ppm}$, $\mathrm{b}_{2}$ sekitar 1,85 ppm, $\mathrm{b}_{3}$ sekitar 1,71 ppm, dan $\mathrm{b}_{4}$ sekitar 2,13 ppm (Jumar dan Saputra, 2020).

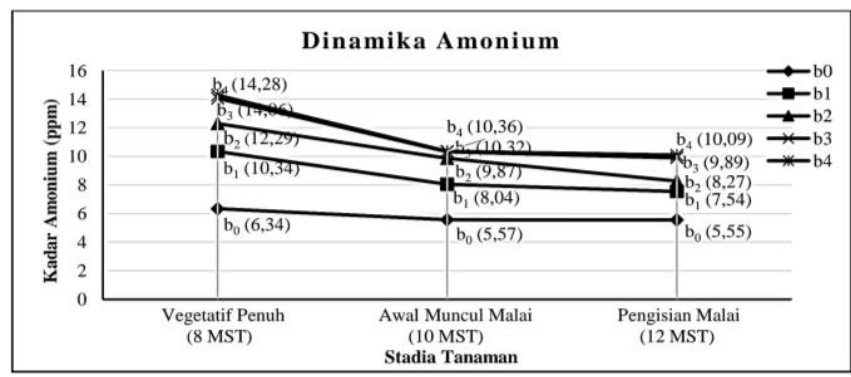

Keterangan: $\mathrm{b}_{0}=0$ ton.ha $\mathrm{a}^{-1} ; \mathrm{b}_{1}=5$ ton.ha ${ }^{-1} ; \mathrm{b}_{2}=10$ ton.ha ${ }^{-1}$; $\mathrm{b}_{3}=15$ ton $\cdot \mathrm{ha}^{-1} ; \mathrm{b}_{4}=20$ ton.ha ${ }^{-1}$.

Gambar 1. Dinamika amonium pada pemberian bokashi limbah baglog jamur tiram di tanah sulfat masam pada beberapa stadia umur padi

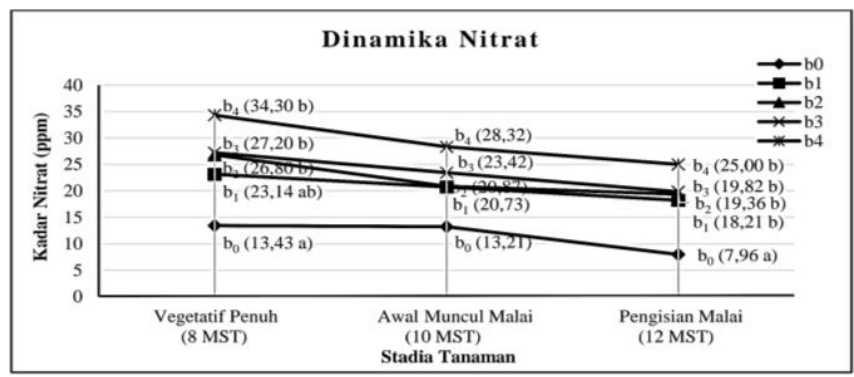

Keterangan: $\mathrm{b}_{0}=0$ ton.ha $\mathrm{a}^{-1} ; \mathrm{b}_{1}=5$ ton.ha ${ }^{-1} ; \mathrm{b}_{2}=10$ ton.ha ${ }^{-1}$; $\mathrm{b}_{3}=15$ ton.hat ${ }^{-1} ; \mathrm{b}_{4}=20$ ton.hat ${ }^{-1}$. Berdasarkan uji DMRT pada taraf 5\% maka huruf yang sama pada grafik menunjukkan perlakuan tidak memberikan pengaruh yang berbeda.

Gambar 2. Dinamika nitrat pada pemberian bokashi limbah baglog jamur tiram di tanah sulfat masam pada beberapa stadia umur padi

Kadar amonium dan nitrat di tanah mengalami kenaikan pada saat di stadia vegetatif penuh. Kenaikan kadar amonium dan nitrat diduga akibat dekomposisi bahan organik tanah dari bentuk organik ke bentuk anorganik. Hal ini sesuai dengan pernyataan Saidy (2018), menjelaskan bahwa proses dekomposisi merupakan pengubahan bahan organik menjadi senyawa-senyawa mineral melalui proses abiotik maupun biotik. Perombakan bahan organik di dalam tanah akan menyebabkan terjadinya mineralisasi unsur hara, sehingga unsur hara yang awalnya tidak tersedia menjadi tersedia untuk tanaman. Meningkatnya kadar amonium dan nitrat akibat pemberian bokashi limbah baglog jamur tiram diduga karena kandungan nitrogen yang terkandung di dalam bokashi limbah baglog jamur tiram. Menurut Suwastika et al. (2018), pembentukan amonium biasanya melalui proses amonifikasi bahan organik atau hidrolisis pupuk N, sedangkan nitrat terbentuk karena proses nitrifikasi amonium. Proses nitrifikasi sangat menentukan ketersediaan ion nitrogen dalam tanah yang dapat digunakan langsung oleh tanaman.

Pemberian bokashi diawal penanaman menyebabkan kadar amonium dan nitrat tercukupi untuk pertumbuhan tanaman hingga mencapai stadia vegetatif penuh, dibandingkan tanpa pemberian bokashi (Gambar 1 dan 2). Ketersediaan amonium dan nitrat di tanah tersebut terlihat pada warna daun yang mendukung pertumbuhan tanaman pada semua perlakuan termasuk kontrol (Gambar 3). Hal tersebut menjadikan amonium dan nitrat pada tanah diduga menjadi sumber unsur pembentuk klorofil yang memberikan warna hijau pada daun. Menurut Faozi dan Wijonarko (2010), menyatakan bahwa pemberian pupuk nitrogen pada tanaman dapat meningkatkan aktivitas nitrat reduktase (ANR) daun, kehijauan warna daun, dan kandungan klorofil daun.

Kadar amonium dan nitrat pada media tanam mengalami penurunan saat stadia awal muncul malai, turunnya kadar amonium dan nitrat diduga karena digunakan dalam pembentukan malai sehingga di dalam tanah kandungan amonium dan nitrat semakin berkurang. Pembentukan malai ini memerlukan nitrogen dalam penyusunannya, sehingga kemunculan malai tidak bisa lepas dari ketersediaan nitrogen. Menurut Patti et al. (2013), menjelaskan bahwa salah satu peranan penting dari nitrogen yaitu pembentukan gabah (malai), dimana N-total tanaman saat pembentukan malai berkisar antara 1,31-1,42\%. Menurut penelitian yang dilakukan oleh Ida et al. (2009), penyerapan nitrogen pada varietas Takanari terus berlanjut sampai 30 hari setelah kemunculan malai dan pada varietas Nipponbare hanya sampai 20 hari setelah kemunculan malai. Padi varietas Takanari nitrogen lebih banyak dikirimkan kebagian malai daripada kebagian daun tanaman jika dibandingkan dengan padi varietas Nipponbare. Perbedaan pendistribusian pada bagian malai sekitar $8 \%$ dan kebagian daun sekitar 5\%.

Kadar amonium dan nitrat di dalam tanah yang menurun ini juga dapat dilihat dari pengamatan warna daun padi, dimana penurunan kadar amonium dan nitrat ini diduga karena diserap oleh tanaman untuk pertumbuhan dan perkembangan hal itu dikarenakan skala warna daun yang diamati mengalami peningkatan. Skala warna daun yang diamati walaupun mengalami kenaikan akan tetapi pada perlakuan $b_{4}$ mengalami penurunan skala warna daun (Gambar 3). Penurunan ini diduga karena pada perlakuan $b_{4}$ ketersediaan unsur hara lebih banyak sehingga saat masa vegetatif tumbuhnya lebih optimal dan saat fase heading munculnya lebih awal dari perlakuan yang lain sehingga mengakibatkan warna daunnya mengikuti fase perkembangan tanaman. Menurut Makarim dan Suhartatik 
(2009), menjelaskan bahwa fase heading membutuhkan waktu sekitar 10-14 hari, dikarenakan perbedaan laju pertumbuhan antar tanaman dan anakan.

Kadar amonium dan nitrat tanah saat stadia pengisian malai juga mengalami penurunan, menurunnya kadar amonium dan nitrat diduga karena tanaman padi menyerap amonium dan nitrat dari tanah dan dikirimkan ke bagian gabah untuk pembentukan protein di dalam gabah. Menurut Hernawan \& Meylani (2016), protein sendiri merupakan makronutrien yang menyusun molekul hidup dan sebagian besar merupakan unsur nitrogen. Nitrogen sendiri sangat diperlukan tanaman padi ketika pengisian malai, agar gabah isi lebih banyak.

Ketersediaan nitrogen pada fase generatif sangat diperlukan oleh tanaman padi, hal ini berkaitan dengan jumlah kandungan protein yang ada di dalam gabah. Menurut Soplanit dan Nukuhaly (2012), menjelaskan bahwa ketersediaan nitrogen saat fase generatif sangat diperlukan, hal ini berkaitan dengan penundaan penuaan daun untuk melakukan fotosintesis saat stadia pengisian gabah serta meningkatkan kadar protein di dalam gabah. Menurut Juliano (1972); Hernawan dan Meylani (2016), menjelaskan bahwa kadar protein yang tinggi pada beras cenderung dipengaruhi oleh pertumbuhan tanaman pada tanah yang tinggi akan unsur nitrogen.

Kadar amonium dan nitrat tanah yang mengalami penurunan pada stadia pengisian malai ini diduga tidak hanya untuk pembentukan protein akan tetapi juga untuk bagian tanaman yang lain, hal ini dapat diketahui dari serapan $\mathrm{N}$ tanaman saat panen (Gambar 4), dimana pada tanah yang diberikan bokashi limbah baglog jamur tiram mempunyai serapan $\mathrm{N}$ yang lebih tinggi jika dibandingkan dengan kontrol. Hal ini diduga karena amonium dan nitrat yang tersedia di tanah terserap dan terakumulasi dibagian tanaman. Menurut Mengel et al. (2001); Putra et al. (2015), meningkatnya unsur hara makro di dalam tanah akan meningkatkan serapan hara oleh tanaman, dimana senyawasenyawa organik akan terbentuk pada jaringan tanaman.

Nilai $\mathrm{pH}$ pada tanah sulfat masam yang digunakan pada penelitian ini tidak menjadi faktor pembatas, karena terjadi perbaikan nilai $\mathrm{pH}$ akibat pemberian bokashi limbah baglog jamur tiram yang menyebabkan penambahan bahan organik ke dalam tanah. Hal tersebut akan menyumbangkan muatan-muatan negatif tanah yang akan mengikat $\mathrm{Al}$ dan $\mathrm{Fe}$ sehingga $\mathrm{pH}$ tanah akan naik, $\mathrm{pH}$ tanah yang naik akan meningkatkan ketersediaan unsur hara. Menurut Zhang \& Zhao (1997); Saidy (2018), menjelaskan bahwa proses pemisahan gugus fungsional dari bahan organik seperti gugus fenolik, quininik, karboksilat, dan hidroksil akan menyumbangkan muatan negatif pada tanah.

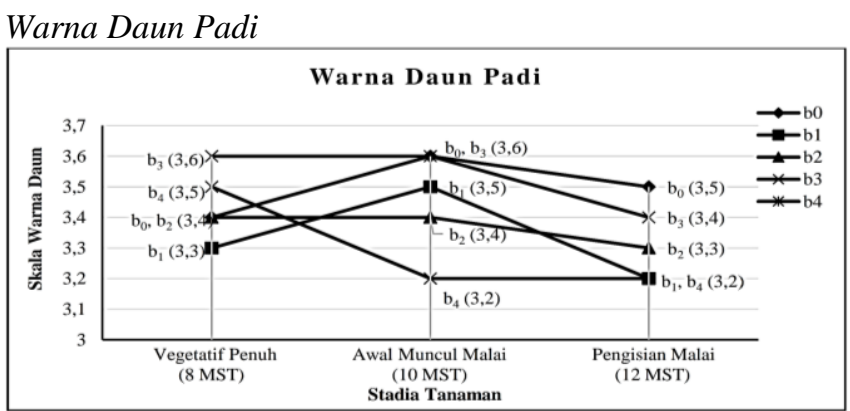

Keterangan: $b_{0}=0$ ton.ha ${ }^{-1} ; b_{1}=5$ ton.ha $a^{-1} ; b_{2}=10$ ton.hat ${ }^{-1}$; $\mathrm{b}_{3}=15$ ton $\cdot \mathrm{ha}^{-1} ; \mathrm{b}_{4}=20$ ton.ha $\mathrm{a}^{-1}$.

Gambar 3. Warna daun padi pada pemberian bokashi limbah baglog jamur tiram di tanah sulfat masam pada beberapa stadia umur padi

Pemberian bokashi limbah baglog jamur tiram tidak memberikan pengaruh nyata terhadap skala warna daun padi di stadia vegetatif penuh pada umur 8 MST, stadia awal muncul malai (10 MST), dan stadia pengisian malai (12 MST) (Gambar 3).

Warna daun pada stadia vegetatif penuh memiliki warna yang beragam. Perbedaan warna daun yang bervariasi pada penelitian ini diduga karena ketersediaan nitrogen di dalam tanah yang diserap oleh tanaman. Menurut Faozi dan Wijonarko (2010), menyatakan bahwa nitrogen pada tanaman padi memiliki fungsi dalam menyusun klorofil serta menunjukkan warna hijau tua pada daun.

Nitrogen tersedia di dalam tanah digunakan untuk pertumbuhan tanaman dan pembentukan anakan, akan tetapi saat kemunculan malai dan pengisian malai nitrogen tersedia mulai berkurang sehingga nitrogen tersedia digunakan untuk pembentukan malai dan pembentukan buah. Menurut Bachtiar et al. (2020), protein yang ada di dalam bulir padi merupakan hasil kiriman dari jerami ke dalam gabah. Terbaginya distribusi nitrogen dari bagian vegetatif tanaman ke bagian generatif tanaman menyebabkan warna daunnya berubah kearah hijau muda. Menurut pendapat Putra et al. (2015), nitrogen merupakan unsur hara utama untuk tanaman dan merupakan penyusun asam amino dalam membentuk protein, berperan dalam masa vegetatif tanaman, dan membuat warna pada daun lebih kehijauan.

Meskipun nitrogen tersedia di tanah pada perlakuan bokashi limbah baglog jamur tiram lebih tinggi dari kontrol, tetapi warna daun pada stadia awal muncul malai dan pengisian malai skala warna daunnya lebih tinggi kontrol daripada yang diberikan perlakuan. Hal tersebut diduga karena nitrogen masih tersisa di dalam tanah dan keterbatasan tanaman padi menyerap unsur hara. Menurut Triyono et al. (2013), kemampuan tanaman padi untuk menyerap amonium dan nitrat dalam pertumbuhannya sangat terbatas. Hal itu diperjelas oleh Singh et al. (1995); Triyono et al. (2013), bahwa kemampuan tanaman padi untuk melakukan penyerapan unsur nitrogen berkisar antara $20-40 \%$ dari pupuk yang diberikan, sehingga sisa nitrogen yang tidak terserap akan terdenitrifikasi, volatilisasi, dan leaching didaerah air tanah.

Perbedaan warna daun ini juga diduga karena fase heading (muncul malai) yang tidak bersamaan. Perbedaan 
laju pertumbuhan ini diduga karena perbedaan ketersediaan nutrisi di tanah, sehingga tanaman terlambat masuk fase generatif. Padahal umur tanaman akan mempengaruhi warna daun apabila pertumbuhannya normal. Hal ini didukung oleh Nurcahya (2019), menjelaskan bahwa seiring bertambahnya umur pertumbuhan tanaman padi maka warna daunnya juga akan semakin berubah. Pengukuran warna daun pada umur 10 minggu dengan menggunakan citra pada variabel kuning didapatkan frekuensi pixel sebanyak 550 pixel yang mengindikasikan warna daunnya ke arah hijau kekuningan. Pengukuran dengan citra pada 12 minggu setelah tanam dengan menggunakan variabel kuning didapatkan frekuensi pixel sekitar 1.000 pixel yang mengindikasikan bahwa warna daunnya hampir kuning semua.

\section{Serapan Nitrogen Tanaman}

Berdasarkan hasil analisis bagian tanaman pada saat panen menunjukkan bahwa serapan $\mathrm{N}$ tanaman berpengaruh sangat nyata dengan pemberian bokashi limbah baglog jamur tiram. Serapan $\mathrm{N}$ tanaman tertinggi terdapat pada perlakuan 20 ton.ha $^{-1}\left(b_{4}\right)$ dan serapan terendah terdapat pada perlakuan 0 ton.ha ${ }^{-1}\left(b_{0}\right)$. Berdasarkan uji lanjut Duncan Multipe Range Test perlakuan $\mathrm{b}_{0}$ berbeda nyata dengan perlakuan lainnya dan perlakuan $b_{4}$ berbeda nyata dengan perlakuan lainnya (Gambar 4).

Pemberian bokashi limbah baglog jamur tiram diduga mampu mengefisiensikan pemupukan urea, karena terjadi peningkatan ketersediaan amonium dan nitrat tanah di daerah perakaran tanaman. Serapan nitrogen tanaman pada pemberian bokashi limbah baglog jamur tiram semakin naik dengan semakin tingginya bokashi yang diberikan ke tanah. Menurut penelitian Bachtiar et al. (2020), bahwa pemberian pupuk kandang yang semakin meningkat menyebabkan semakin meningkat pula penyerapan nitrogen yang dapat diserap oleh buah dan tanaman.

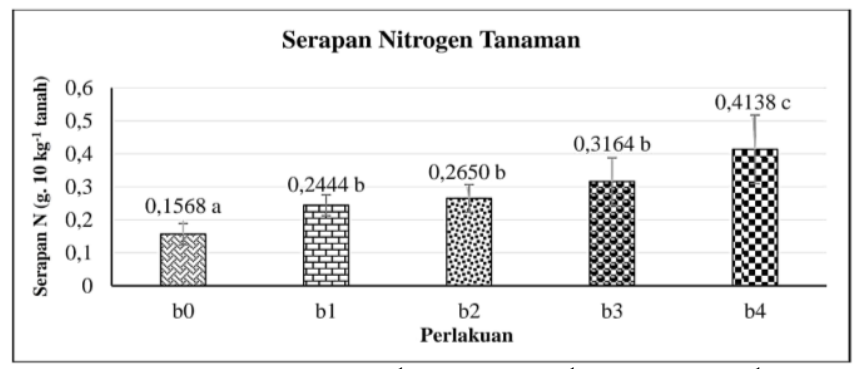

Keterangan: $b_{0}=0$ ton.h ${ }^{-1} ; b_{1}=5$ ton.ha $a^{-1} ; b_{2}=10$ ton.ha ${ }^{-1} ; b_{3}=15$ ton.ha ${ }^{-1} ; b_{4}=20$ ton.ha ${ }^{-1}$. Berdasarkan uji DMRT pada taraf $5 \%$ maka huruf yang sama pada grafik menunjukkan perlakuan tidak memberikan pengaruh yang berbeda.

Gambar 4. Serapan nitrogen tanaman pada pemberian bokashi limbah baglog jamur tiram di tanah sulfat masam

Ketersediaan nitrogen di dalam tanah juga mempengaruhi serapan tanaman. Nitrogen yang diserap oleh tanaman berupa bentuk amonium dan nitrat, dimana pada penelitian ini semua tanah yang diberikan bokashi limbah baglog jamur tiram memiliki ketersediaan nitrogen lebih tinggi dari kontrol. Hal ini di duga karena bahan organik berperan dalam menyuplai nitrogen di tanah. Menurut Mengel et al. (2001); Putra et al. (2015), menjelaskan bahwa tersedianya nitrogen untuk tanaman berhubungan dengan peningkatan kapasitas tanah dalam menyuplai nitrogen akibat penambahan bahan organik.

\section{Kesimpulan}

Kadar amonim dan nitrat menunjukkan dinamika yang sama setelah penambahan bokashi limbah baglog jamur di tanah sulfat masam pada stadia vegetatif penuh, awal mucul malai, dan pengisian malai tanaman padi. Meskipun tidak terdapat perbedaan warna daun, namun terjadi peningkatan serapan nitrogen. Belum diperoleh dosis terbaik pada hampir semua parameter pengamatan, namun pada dosis 20 ton.ha ${ }^{-1}$ atau setara dengan 85,47 g. $10 \mathrm{~kg}^{-1}$ tanah menunjukkan pengaruh paling baik terhadap semua parameter yang diamati.

\section{Ucapan Terima Kasih}

Terima kasih kepada Tim PNBP 2020 yang dipimpin oleh Bapak Ir. Jumar, M.P. Bapak Riza Adrianoor Saputra, S.P., M.P. dan Ibu Nukhak Nufita Sari, S.P., M.Sc. selaku pihak yang telah membiayai penelitian ini.

\section{Daftar Pustaka}

Annisa, W., Purwanto, B.H., 2010. Retensi P oleh oksida besi di tanah sulfat masam setelah reklamasi lahan. Jurnal Sumber Daya Lahan 4 (1), 47-56.

Bachtiar, T., Robifahmi, N., Flatian, A.N., Slamet, S., \& Citraresmini, A., 2020. Pengaruh dan kontribusi pupuk kandang terhadap $\mathrm{N}$ total, serapan $\mathrm{N}(15 \mathrm{~N})$, dan hasil padi sawah (Oryza sativa L.) varietas mira-1. Jurnal Sains dan Teknologi Nuklir Indonesia 21 (1), 35-48.

Badan Pusat Statistik Provinsi Kalimantan Selatan., 2014. Kalimantan Selatan dalam Angka. Badan Pusat Statistik Provinsi Kalimantan Selatan, Banjarmasin.

Balai Penelitian Tanah (Balittan)., 2009. Petunjuk Teknis Analisis Kimia Tanah, Tanaman, Air, dan Pupuk. Balai Penelitian Tanah, Departemen Pertanian, Bogor.

Departemen Pertanian (Deptan)., 2007. Rekomendasi Pemupukan N, P, dan K pada Padi Sawah Spesifikasi Lokasi. Departemen Pertanian, Jakarta.

Erythrina., 2016. Bagan warna daun: alat untuk meningkatkan efisiensi pemupukan nitrogen pada tanaman padi. jurnal Litbang Pertanian 35 (1), 1-10

Faozi, K. \& Wijonarko, B.R., 2010. Serapan nitrogen dan beberapa sifat fisiologi tanaman padi sawah dari berbagai umur pemindahan bibit. Jurnal Pengembangan Pedesaan 10 (2), 93-101.

Hasbiah, A.W., Yustiani, Y.M., \& Desiriani, N.S., 2017. Pengomposan limbah baglog jamur tiram secara anaerobik dengan variasi aktivator, kotoran kambing dan urea di Desa Cisarua, Lembang Kabupaten Bandung Barat. Proceeding of Community Development 1, 205-215.

Hernawan, E. \& Meylani, V., 2016. Analisis karakteristik fisikokimia beras putih, beras merah, dan beras hitam (Oryza sativa L., Oryza nivara dan Oryza sativa L. Indica). Jurnal Kesehatan Bakti Tunas Husada 15 (1), 79-91

Hunaepi, Dharmawangsa, I.D., Samsuri, T., Mirawati, B., \& Asy’ari, M., 2018. Pengolahan limbah baglog jamur tiram menjadi pupuk organik komersil. Jurnal SOLMA 7 (2), 277-288.

Ida, M., Ohsugi, R., Sasaki, H., Aoki, N., \& Yamagishi, T., 2009. Contribution of nitrogen absorbed during ripening period to grain filling in a high-yielding rice variety, Takanari. Plant Prod. Sci 12 (2), 176-184.

Jumar \& Saputra, R.A., 2020. Laporan Akhir Program Dosen Wajib Meneliti: Optimalisasi Pemanfaatan Limbah Baglog Jamur Tiram untuk Perbaikan Sifat Kimia Tanah Sulfat Masam Hubungannya 
dengan Pertumbuhan, Serapan Hara, dan Produksi Padi. Universitas Lambung Mangkurat, Banjarmasin.

Kementerian Pertanian (Kementan)., 2019. Statistik Lahan Pertanian 20142018. Kementerian Pertanian, Jakarta

Makarim, A.K. \& Suhartatik, E., 2009. Morfologi dan Fisiologi Tanaman Padi. Balai Besar Penelitian Tanaman Padi, 295-330 hlm.

Nurcahya, E.D., 2019. Ekstraksi fitur pertumbuhan padi berdasar warna daun menggunakan analisa ruang warna Hue Saturation Value. Multitek Indonesia 13 (1), 24-33.

Patti, P.S., Kaya, E., \& Silahooy, C.H., 2013. Analisis status nitrogen tanah dalam kaitannya dengan serapan $\mathrm{N}$ oleh tanaman padi sawah di Desa Waimital, Kecamatan Kairatu, Kabupaten Seram Bagian Barat. Agrologia 2 (1), 52-58.

Permatasari, P., Anantanyu, S., \& Dewi, W.S., 2018. Pengaruh tingkat adopsi budidaya padi organik terhadap keberlanjutan budidaya padi organik di Kabupaten Boyolali. Caraka Tani: Journal of Sustainable Agric 33 (2), 153-168.

Putra, C.R., Wahyudi, I., \& Hasanah, U., 2015. Serapan N (nitrogen) dan produksi bawang merah (Allium ascalonicum L.) varietas Lembah Palu akibat pemberian bokashi titonia (Titonia diversifolia) pada entisol Guntarano. e-J. Agrotekbis 3 (4), 448-454.

Saidy, A.R., 2018. Bahan Organik Tanah: Klasifikasi, Fungsi dan Metode Studi. Lambung Mangkurat University Press, Banjarmasin.

Saputra, R.A., \& Sari, N.N., 2021. Ameliorant engineering to elevate soil $\mathrm{pH}$, growth, and productivity off paddy on peat and tidal land. IOP Conf. Ser.: Earth Environ. Sci 1-8.

Soplanit, R. \& Nukuhaly, S.H., 2012. Pengaruh pengelolaan hara NPK terhadap ketersediaan $\mathrm{N}$ dan hasil tanaman padi sawah (Oryza sativa L.) di Desa Waelo Kecamatan Waeapo Kabupaten Buru. Agrologia 1 (1), 81-90.

Suwastika, A.A.N.G., Soniari, N.N., \& Kesumadewi, A.A.I., 2018. Biologi Tanah. Prodi Agroekoteknologi Fakultas Pertanian Universitas Udayana, Denpasar.

Triyono, A., Purwanto, \& Budiyono., 2013. Efisiensi penggunaan pupuk $\mathrm{N}$ untuk pengurangan kehilangan nitrat pada lahan pertanian. Prosiding Seminar Nasional Pengelolaan Sumber Daya Alam dan Lingkungan 2013, 526-531. 